\title{
Décoloration blanchâtre des dents post-anesthésie
}

\author{
Annick Bécotte, MD, FRCPC (1) - Laurie St-Pierre, DMD, MS
}

Received: 13 November 2018/Revised: 15 November 2018/Accepted: 16 November 2018/Published online: 9 January 2019

(C) Canadian Anesthesiologists' Society 2019

Plusieurs altérations dentaires associées à une anesthésie générale sont possibles. Nous présentons un cas inédit dans la littérature anesthésique de décoloration dentaire post-anesthésique chez un jeune patient en bonne santé.

Il s'agit d'un jeune homme de 17 ans, sans antécédent médical particulier qui se présente à la salle d'opération pour une chirurgie orthopédique. À l'examen pré-anesthésique, les voies aériennes sont sans particularité, les dents sont saines et sans restauration. Il n'a jamais eu de traitement d'orthodontie ou de blanchiment des dents.

Le patient reçoit une anesthésie générale induite avec du propofol et du fentanyl. Le maintien est fait au sévoflurane. Le masque laryngé $\left(\right.$ LMA $\left.{ }^{\circledR}\right)$ Supreme de Teleflex Medical (Westmeath, Irlande) taille 4, est facile d'insertion avec environ $2 \mathrm{~mL}$ de gelée de lubrifiante hydrosoluble (type MUKO). La pression n'est pas vérifiée car elle semble adéquate au niveau du ballonnet témoin. Les paramètres ventilatoires de la machine Datex-Ohmeda AISYS (GE Healthcare, Madison, WI, É.-U.) sont AiPro $15 \mathrm{cmH}_{2} \mathrm{O}$ pour des volumes courants moyens d'environ $650 \mathrm{~mL}$, débit de gaz frais à $2 \mathrm{~L} \cdot \mathrm{min}^{-1}$. Aucune fuite nécessitant un débit de gaz supplémentaire n'est notée. La procédure d'une durée de $60 \mathrm{~min}$ se déroule sans problème. L'émergence de l'anesthésie se fait de façon douce et le patient serre, tout au plus, les incisives sur la partie du cale-dent du LMA.

\footnotetext{
A. Bécotte, MD, FRCPC ( $\square)$

Hôtel-Dieu d'Arthabaska, CIUSSS Mauricie et Centre-du-

Québec, Victoriaville, QC, Canada

e-mail: annick.becotte@usherbrooke.ca

L. St-Pierre, DMD, MS

Faculté de Médecine Dentaire, Université Laval, Quebec, QC, Canada
}

Le patient se réveille non-soufrant et rapporte rapidement une sensation anormale, mais non-douloureuse au niveau de ses incisives supérieures. À l'examen dentaire en salle de réveil, effectué par l'anesthésiologiste, on note une apparence blanchâtre, opaque et sans lustre localisée aux tiers incisifs des incisives centrales supérieures avec un pourtour assez franc et linéaire (Figure, panneau A). La portion linguale des dents, observée avec un miroir dentaire, est sans particularité. Une consultation téléphonique au chirurgien maxillo-facial de garde est faite et la Figure lui est envoyée. L'anesthésiologiste a constaté la résolution complète de la condition le lendemain, soit moins de dix heures après le diagnostic présomptif (Figure, panneau B).

L'apparition nouvelle d'une zone blanchâtre sans lustre, aux tiers incisifs des incisives centrales supérieures avec un pourtour laissant présager qu'il puisse s'agir d'une portion de dent non recouverte par la lèvre supérieure lors de l'intervention est en faveur d'un diagnostic de déshydratation de l'émail. ${ }^{1,2}$ Celle-ci se produit, lorsque, suite à une exposition à l'air, l'eau se trouvant entre les bâtonnets d'émail est remplacée par de l'air changeant l'indice de réfraction de l'émail et lui conférant une apparence blanche et opaque.

Le diagnostic différentiel des lésions blanches inclut la fluorose, les lésions carieuses débutantes, l'hypoplasie de l'émail, un blanchiment induit. Chacune de ses conditions est toutefois chronique et aurait été notée à l'évaluation pré-anesthésique.

Bien qu'elle soit impressionnante et méconnue, cette condition est sans conséquence autre que l'inquiétude liée à la crainte d'un traumatisme dentaire permanent. Un anesthésiologiste avisé de l'existence et de l'histoire naturelle de cette entité saura réassurer son patient en ce qui a trait à son caractère bénin et auto-résolutif. 

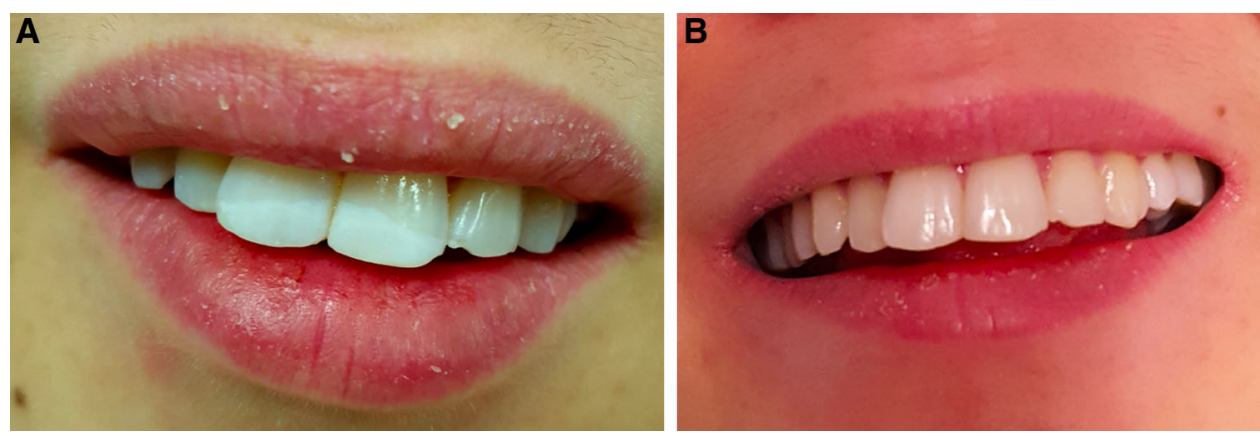

Figure (A) Dents en post-anesthésie (21h20). On peut noter la démarcation franche de la coloration de l'émail. B) Dents le lendemain matin (après un délai de 9h30)

\section{Whitish tooth discolouration following anesthesia}

There are several possible dental risks associated with a general anesthesia. We present a novel case report of postanesthetic tooth discolouration in a young and healthy patient.

A 17-yr-old male patient with no medical history presented in the operating room for orthopedic surgery. The upper airways showed no specific issues or concerns during the pre-anesthesia assessment. The patient's teeth were healthy with no prior restorative dental work performed and he had received no other orthodontic treatment or teeth whitening.

The patient had general anesthesia induced with propofol and fentanyl with maintenance using sevoflurane. The Teleflex Medical (Westmeath, Ireland) LMA Supreme supraglottic airway (size 4) was easily inserted with approximately $2 \mathrm{~mL}$ of water-soluble lubricant gel $\left(\mathrm{MUKO}{ }^{\circledR}\right.$ lubricating jelly). Pressure was not checked as it seemed appropriate in the pilot balloon. The ventilator settings of the Datex-Ohmeda AISYS (GE Healthcare, Madison, WI, USA) machine were an inspiratory pressure of $15 \mathrm{cmH}_{2} \mathrm{O}$ delivering mean tidal volumes of approximately $650 \mathrm{~mL}$; the fresh gas flow was set at $2 \mathrm{~L} \cdot \mathrm{min}^{-1}$. No airway leakage (requiring any additional gas flow) was noted and the 60 -min procedure was uneventful. The patient emerged smoothly from anesthesia, with only some tightening of his teeth on the bite block of the LMA.

The patient woke up with no specific pain, but soon reported an abnormal (non-painful) feeling in his upper incisors. During the dental examination performed by the anesthesiologist in the postanesthesia care unit, a dull
(A) Teeth post-anesthesia (9:20 pm) following an uneventful $60 \mathrm{~min}$ anesthetic using a supraglottic airway. The whitish area, with a linear border, of enamel colouration only present on the front of the teeth can be seen. B) The teeth on the following morning (less than nine hours and $30 \mathrm{~min}$ later), with the enamel discoloration now resolved

opaque and whitish surface on the lower third of the upper central incisors was observed, with a well-defined linear border (Figure, panel A). The inside aspect of the teeth, examined with a dental mirror, shows no specific changes. The teeth showed complete resolution of the condition the following day, less than ten hours after the tentative diagnosis (Figure, panel B).

After consultation with the on-call maxillofacial surgeon, it was felt that the onset of a new whitish area at the incisive thirds of the upper central incisors with a delineation suggesting it could be from part of the tooth not being covered by the upper lip during the surgery resulting in enamel dehydration. ${ }^{1,2}$ It can occur when, following an exposure to air, the water found between the enamel rods is replaced with air, changing the enamel refraction index, and resulting in a white and opaque appearance.

The differential diagnosis for similar-appearing white lesions includes fluorosis, early tooth decay, enamel hypoplasia and exogenous whitening. However, all of those are chronic conditions that would likely have been noticed during the pre-anesthetic assessment.

While visually impressive and not commonly known to anesthesiologists, this enamel dehydration has no clinical consequences, other than the transient fear and anxiety of possible permanent dental trauma. Anesthesiologists aware of its existence and natural history will know how to reassure their patients about its benign and self-resolving nature.

Conflit d'intérêt Aucun déclaré.

Responsabilité éditoriale Cet article a été traité par le $\mathrm{D}^{\mathrm{r}}$ Étienne de Médicis, Rédacteur de la langue française, Journal canadien d'anesthésie.

Conflicts of interest None declared. 
Editorial responsibility This submission was handled by Dr. Étienne de Médicis, French Language Editor, Canadian Journal of Anesthesia.

\section{References}

1. Zhang $D$, Mao $C$, Lu $C$, Romberg $E$, Arola $D$. Dehydration and the dynamic dimensional changes within dentin and enamel. Dent Mater 2009; 25: 937-45.
2. Brodbelt RH, O'Brien WJ, Fan PL, Frazer-Dib JG, Yu R. Translucency of human dental enamel. J Dent Res 1981; 60: 1749-53.

Publisher's Note Springer Nature remains neutral with regard to jurisdictional claims in published maps and institutional affiliations. 